\title{
SERUM TOTAL CALCIUM, SERUM IONIZED CALCIUM AND SERUM ALBUMIN LEVELS IN PATIENTS WITH ESSENTIAL HYPERTENSION AND THEIR FIRST DEGREE RELATIVES
}

Arpita B. Patel ${ }^{1}$, N. Haridas ${ }^{2}$, Hitesh Shah ${ }^{3}$

HOW TO CITE THIS ARTICLE:

Arpita B. Patel, N. Haridas, Hitesh Shah. "Serum Total Calcium, Serum Ionized Calcium and Serum Albumin Levels in patients with Essential Hypertension and their First Degree Relatives". Journal of Evolution of Medical and Dental Sciences 2014; Vol. 3, Issue 06, February 10; Page: 1354-1360, DOI: 10.14260/jemds/2014/1991

ABSTRACT: Calcium plays an important role in pathophysiology of essential hypertension. (1) Serum total calcium, serum ionized calcium and serum albumin levels were measured in 50 subjects with essential hypertension and 50 first degree relatives with familial history of hypertension. The same were also measured in 50 normotensive subjects and 50 first degree relatives having no familial history of hypertension. The results showed that serum total calcium and serum albumin levels were significantly decreased in both males and females with essential hypertension and their first degree relatives when compared with their corresponding controls. While serum ionized calcium levels were not significantly different in hypertensives and their first degree relatives.

KEYWORDS: Essential hypertension, First degree relatives, controls.

INTRODUCTION: Hypertension is a cardiac chronic medical condition in which the systemic arterial blood pressure is elevated. ${ }^{1}$ Hypertension is classified as either primary or secondary. About 90 95\% of causes are categorized as primary hypertension which means high blood pressure with no obvious medical cause. ${ }^{2}$ The remaining $5-10 \%$ cases are caused by other conditions that affect the kidneys, arteries, heart or endocrine system. ${ }^{3}$ Essential hypertension is the most prevalent hypertension type, affecting $90-95 \%$ of hypertensive patients. Essential hypertension is associated with disturbed calcium metabolism. The calcium ions play a major role as a second messenger in excitation contraction coupling in cardiac and smooth muscle cells. ${ }^{4}$

Low serum albumin concentrations appear to be associated with an increased risk of coronary diseases in both sexes and could help along with traditional risk factors in identifying people at risk of myocardial infarction. ${ }^{5}$

As the results reported by various authors on serum total calcium ${ }^{1,6,7}$ and serum albumin 8 were found to be varying, it was planned to study serum total calcium, serum ionized calcium and serum albumin levels in patients with essential hypertension, their first degree relatives and in normal controls.

MATERIALS AND METHODS: The blood samples were collected from 50 hypertensives, 50 first degree relatives with familial history of hypertension, 50 normotensive subjects and 50 first degree relatives having no familial history of hypertension. The subjects included both males and females. The blood was collected in plain vacutte by venepuncture. The samples were centrifuged and serum was used for measurements.

Serum total calcium estimation was done on an automated analyzer, COBAS INTEGRA 400 Plus. Method is according to Schwarzenbach with O- cresolphthelein (O- CPC) complex one. Calcium 
ions react with 0 - cresolphthelein under alkaline conditions to form a violet colored complex. The addition of 8- hydroxyl quinoline prevents interference by Magnesium and ferric ions. ${ }^{9}$

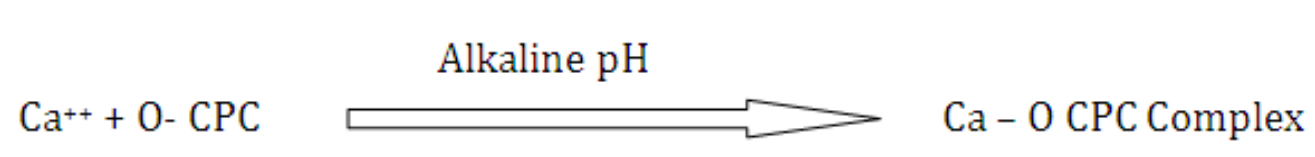

The color intensity of the complex formed is directly proportional to the calcium concentration. It is determined by measuring the increase in absorbance at $552 \mathrm{~nm}$. The value is expressed in $\mathrm{mg} / \mathrm{dl} .{ }^{9}$

Serum ionized calcium measurement was done on AVL 9180 Electrolyte Analyzer. The AVL 9180 Electrolyte Analyzer methodology is based on the ion selective electrode measurement principle to precisely determine the measurement value. ${ }^{10}$

The serum albumin estimation was done by colorimetric method on RA 50 Chemistry Analyzer. The test procedure is followed by manufacturer's instructions and absorbance is taken as optical density. ${ }^{11}$

Albumin in a buffered solution reacts with the anionic bromocresol green (BCG) with a dye binding reaction to give a proportionate green color, which is measured at $620 \mathrm{~nm}$. The final color is stable for 10 minutes. ${ }^{11}$

The concentration of Albumin in a sample from absorbance is calculated by the following formula:

$$
\text { Concentration of Test }=\frac{\text { OD of Test }}{\text { OD of Standard }} \times \text { Concentration of Standard }
$$

The value is expressed in $\mathrm{g} / \mathrm{dl}$.

RESULTS: The results of the study are depicted in tables 1 and 2. The serum total calcium, serum ionized calcium and serum albumin levels in hypertensives and their first degree relatives and normotensives and their first degree relatives are shown in table no.1.

\begin{tabular}{|c|c|c|c|c|c|c|c|c|}
\hline \multirow{2}{*}{ Tests } & \multicolumn{2}{|c|}{$\begin{array}{c}\text { 95\% C.I. for } \\
\text { Hypertensives }\end{array}$} & \multicolumn{2}{|c|}{$\begin{array}{c}\text { 95\% C.I. for } \\
\text { Controls of } \\
\text { normotensives }\end{array}$} & $\begin{array}{c}\text { 95\% C.I. for First } \\
\text { degree relatives } \\
\text { (FDR) of } \\
\text { hypertensives }\end{array}$ & \multicolumn{2}{|c|}{$\begin{array}{c}\text { 95\% C.I. for } \\
\text { Controls (FDR) of } \\
\text { normotensives }\end{array}$} \\
\cline { 2 - 9 } & $\mathrm{N}$ & Mean \pm SD & $\mathrm{N}$ & Mean \pm SD & $\mathrm{N}$ & Mean \pm SD & $\mathrm{N}$ & Mean \pm SD \\
\hline $\begin{array}{c}\text { Total calcium } \\
\text { (mg/dl) }\end{array}$ & 50 & $8.35 \pm 0.63$ & 50 & $9.53 \pm 0.51$ & 50 & $8.81 \pm 0.59$ & 50 & $9.33 \pm 0.45$ \\
\hline $\begin{array}{c}\text { Ionized } \\
\text { calcium(mmol/L) }\end{array}$ & 50 & $1.11 \pm 0.11$ & 50 & $1.14 \pm 0.085$ & 50 & $1.14 \pm 0.089$ & 50 & $1.15 \pm 0.083$ \\
\hline $\begin{array}{c}\text { Albumin } \\
\text { (g/dl) }\end{array}$ & 50 & $4.07 \pm 0.75$ & 50 & $4.61 \pm 0.45$ & 50 & $4.35 \pm 0.64$ & 50 & $4.61 \pm 0.39$ \\
\hline
\end{tabular}

TABLE N0.1: Serum total calcium, serum ionized calcium and serum albumin levels in hypertensives and their first degree relatives and normotensives and their first degree relatives

C.I. = confidence interval 


\begin{tabular}{|c|c|c|c|c|c|c|}
\hline \multirow[t]{2}{*}{ Parameter } & \multirow[t]{2}{*}{$\begin{array}{l}\text { Category } \\
\mathbf{N}=\mathbf{5 0}\end{array}$} & \multirow[t]{2}{*}{ Mean \pm SD } & \multirow[t]{2}{*}{$\begin{array}{c}\text { Mean } \\
\text { difference }\end{array}$} & \multirow[t]{2}{*}{ P Value } & \multicolumn{2}{|c|}{$\begin{array}{l}\text { 95\% confidence } \\
\text { interval of the } \\
\text { difference }\end{array}$} \\
\hline & & & & & Lower & upper \\
\hline \multirow{2}{*}{$\begin{array}{l}\text { Total calcium } \\
(\mathrm{mg} / \mathrm{dl})\end{array}$} & Hypertensives & $8.35 \pm 0.63$ & -1.179 & $<0.0001$ & -1.40 & -0.95 \\
\hline & Normotensives & $9.53 \pm 0.51$ & & & & \\
\hline \multirow{2}{*}{$\begin{array}{l}\text { Ionized calcium } \\
(\mathrm{mmol} / \mathrm{L})\end{array}$} & Hypertensives & $1.11 \pm 0.11$ & -0.035 & 0.088 & -0.07 & 0.01 \\
\hline & Normotensives & $1.14 \pm 0.085$ & & & & \\
\hline \multirow{2}{*}{ Albumin (g/dl) } & Hypertensives & $4.07 \pm 0.75$ & -0.544 & $<0.0001$ & -0.79 & -0.29 \\
\hline & Normotensives & $4.61 \pm 0.45$ & & & & \\
\hline \multirow{2}{*}{$\begin{array}{c}\text { FDR } \\
\text { Total calcium } \\
(\mathrm{mg} / \mathrm{dl})\end{array}$} & Hypertensives & $8.81 \pm 0.59$ & -0.520 & $<0.0001$ & -0.73 & -0.31 \\
\hline & Normotensives & $9.33 \pm 0.45$ & & & & \\
\hline \multirow{2}{*}{$\begin{array}{c}\text { FDR } \\
\text { Ionized } \\
\text { calcium(mmol/L) }\end{array}$} & Hypertensives & $\begin{array}{c}1.14 \\
\pm 0.089\end{array}$ & -0.008 & 0.629 & -0.04 & 0.020 \\
\hline & Normotensives & $1.15 \pm 0.083$ & & & & \\
\hline \multirow{2}{*}{$\begin{array}{c}\text { FDR } \\
\text { Albumin (g/dl) }\end{array}$} & Hypertensives & $4.35 \pm 0.64$ & -0.266 & 0.014 & -0.48 & -0.05 \\
\hline & Normotensives & $4.61 \pm 0.39$ & & & & \\
\hline
\end{tabular}

$<0.05=$ significant difference

- When serum total calcium levels of hypertensives and normotensives were compared, the P value mean total calcium level of normotensives had statistically significant higher values than the mean total calcium levels of hypertensives.

- When serum albumin levels of hypertensives and normotensives were compared, the mean albumin level of normotensives had statistically significant higher values than the mean albumin levels of hypertensives.

- When serum ionized calcium levels of hypertensives and normotensives were compared, the mean ionized calcium level of normotensives had slightly higher values. But there was no statistically significant difference between mean ionized calcium levels of hypertensive and normotensive groups.

The mean \pm SD of serum total calcium levels in normotensives were $9.53 \pm 0.51$ and the same was found to be decreased in hypertensive groups $(8.35 \pm 0.63)$. We found that there was statistically significant difference between mean total calcium levels in males of hypertensives and normotensives category. We also found that there was statistically significant difference between mean total calcium levels in females of hypertensives and normotensives category. When the first degree relatives were considered, the first degree relatives of hypertensives had statistically significant lower mean \pm SD serum total calcium levels $(8.81 \pm 0.59)$, when compared to the first degree relatives of normotensive $(9.33 \pm 0.45)$. $P$ value is $<0.05$. 
The mean \pm SD serum albumin levels in normotensives were $4.61 \pm 0.39$ and the same was decreased for hypertensive groups $(4.07 \pm 075)$. We found that there was statistically significant difference between mean albumin levels in males of hypertensives and normotensives category. We also found that there was statistically significant difference between mean albumin levels in females of hypertensives and normotensives category. When the first degree relatives were considered, the first degree relatives of hypertensives had statistically significant lower mean \pm SD serum albumin levels (4.35 \pm 0.64$)$, when compared to the first degree relatives of normotensives $(4.61 \pm 0.39)$. $P$ value is $<0.05$.

The mean \pm SD serum ionized calcium levels in normotensives were $1.14 \pm 0.085$ and the same were comparable without any statistically significant difference in hypertensive groups (1.11 \pm 0.11 ). We found that there was no statistically significant difference between mean ionized calcium levels in males of hypertensives and normotensives category. We also found that there was no statistically significant difference between mean ionized calcium levels in females of hypertensives and normotensives category. When the first degree relatives were considered, the first degree relatives of hypertensives had slightly lower mean \pm SD ionized calcium level $(1.14 \pm 0.089)$, but there was no statistically significant difference when compared to the first degree relatives of normotensives $(1.15 \pm 0.083)$, $\mathrm{P}$ value is $>0.05$.

DISCUSSION: Essential hypertension is associated with disturbed calcium metabolism. Individuals with high diastolic blood pressure had significantly lower total serum calcium. ${ }^{6}$ The free intracellular calcium concentration determines the tension in vascular smooth muscle cells thereby resulting in peripheral vascular resistance. ${ }^{1}$ Zidek et al found an increased intravascular calcium concentration in normotensive subjects with familial hypertensive disposition in comparison with Normotensives without family history of hypertension. ${ }^{12}$

Touyz et al showed significantly increased intracellular calcium levels in essential hypertension. ${ }^{13}$ Some authors have reported lower concentration of serum calcium in hypertensive than in normotensive subjects. ${ }^{14,15}$

The present study shows significantly reduced serum total calcium and albumin levels in hypertensives. While the serum ionized calcium levels are comparable in both groups as there is no significant difference. This is in agreements with studies of K. Sudhakar et al ${ }^{1}$ and Reichel et al. 6

Serum calcium levels were also found to be significantly lower by Fu. Y., Wang et $\mathrm{al}^{14}$ and Touyz. R. M. et al. ${ }^{16}$ Reichel et al also reported reduced calcium level in males with elevated diastolic blood pressure. ${ }^{6}$ Kosch et al did not find any change in serum calcium levels in hypertensives when compared to controls. Membrane calcium content was significantly increased in patients with untreated primary hypertension and correlated to blood pressure levels in their studies. The data suggested that membrane mechanism may contribute to alterations in calcium metabolism and to the pathogenesis of primary hypertension. ${ }^{7}$

Abnormal cellular ion transport resulting in altered membrane control over intracellular calcium may be related to essential hypertension. Changes in magnesium level may contribute to altered cell membrane, calcium binding in essential hypertension. ${ }^{17}$ Alterations in intracellular calcium are thought to be involved in the common pathway mediating the secretion and action of many hormones including the pressure action of catecholamines and Angiotensin II. Intracellular calcium may be involved in regulation of blood pressure. Calcium regulating hormones like 1, 25- 
Dihydroxy vitamin D levels of plasma, renin activity, and circulating ionized calcium contribute to the pathophysiology of the essential hypertension. ${ }^{18,19}$

Yogesh R Pawade et al studied at Nagpur, had found that Serum total calcium was found to be same in the hypertensive as well as the normotensive population but serum ionized calcium was observed to be decreased in the hypertensive subjects as compared to the normotensive subjects. Decreased levels of serum ionized calcium are associated with essential hypertension. ${ }^{20}$ But in our study, the serum ionized calcium levels in normotensives and hypertensives were not significantly different. However, this author has not studied on serum albumin levels. These results are not matching with my study.

Albumin has low affinity and high capacity binding potential for most of the molecules that may be the actual unmeasured substances regulating blood pressure. Serum albumin has been demonstrated to have a blood pressure lowering effect in animal studies. Serum albumin is also associated with systolic blood pressure and diastolic blood pressure. ${ }^{8}$

\section{CONCLUSION:}

(1) The serum total calcium levels are found to be lower in hypertensive males and females in comparison to the corresponding controls. The serum total calcium levels are also found to be lower in the first degree relatives of the hypertensives when compared with the corresponding controls. The data correlates well with the other previous studies.

(2) The study shows that there is no significant difference in serum ionized calcium levels of hypertensives when compared to the corresponding controls. The levels are also comparable in the first degree relatives of hypertensives and corresponding controls.

(3) Our study shows that there is significant decrease in serum albumin levels in hypertensives and their first degree relatives when compared with the corresponding controls.

(4) The present study shows there may be a role of serum total calcium in the pathophysiology of hypertension, although, further studies are required to confirm these observations.

(5) Serum total calcium and serum albumin estimation may be used to predict the risk of hypertension in normotensives with familial history of hypertension.

\section{REFERENCES:}

1. "Hypertension" (in en) (html). "Normal blood pressure is when your blood pressure is lower than 120/80 mmHg most of the time". PubMed. Health. 2011.10.06Retrieved 2011.10.16.

2. Carretero OA, Oparil S. "Essential Hypertension, Part I: definition and etiology". Circulation 2000; 101(3):329-35.

3. Secondary Hypertension, Mayo foundation for medical education and research (2008) [1], Retrieved May 10, 2010.

4. K. Sudhakar, M. Sujatha, S. Rameshbabu, P. Padmavathi and P.P Reddy. Serum calcium levels in patients with essential hypertension and their first degree relatives. Ind $\mathrm{J}$ of clinical Biochemistry, 2004, 19(1) 21-23.

5. DM Vasudevan, Sreekumari S. Textbook of Biochemistry for Medical students, $4^{\text {th }}$ Ed. 2005; C (21): 222-223, D(28): 300-303.

6. Reichel H, Leibethal R., Hense, H.W., Schmidt, G.H., and Ritz, E. Disturbed calcium metabolism in subjects with elevated diastolic blood pressure. Clin. Investing. 1992: 70, 748-751. 
7. Kosch M., Hausberg M., Barembrock M., Posadzy-malaczynskas A., Rahn KH, Kisters K. Increased membranous calcium concentrations in primary hypertension: a causal link to pathogenesis. J. Hum. Hypertens. 2001:15,37-40.

8. Howard Hu, David Sparrow and Scott Weiss. Association of serum albumin with blood pressure in the normative aging study. American Journal of Epidemiology, 1992; 136 (12), 1465-1473.

9. COBAS Integra 400 plus Method's Manual. A -1 (4-12).

10. AVL 9180 Electrolyte analyzer operator's manual.

11. RA 50 Chemistry Analyzer Operating Manual; 1 (1.2), 6 (6.1).

12. Zidek W., Vetter H., Dorst K. G. Zumkley H. and Loose H. Intracellular $\mathrm{Na}^{+}$and $\mathrm{Ca}^{++}$activities in essential hypertension. Clinical Science. 1982; 63, 41S-43S.

13. Touyz R. M. and Milne F.J. Alterations in intracellular cations and cell membrane ATPase activity in patients with malignant hypertension. J. Hypertens., 1995; 13,867-874.

14. Fu Y., Wang S., Lu Z., Li H. and Li S. Erythrocyte and plasma $\mathrm{Ca}^{++}, \mathrm{Mg}^{++}$and cell membrane adenosine triphosphatase activity in patients with essential hypertension. Clin. Med. J. (Engl), 1998; 111, 147-149.

15. Touyz R. M., Milne F.J. and Reinach S. G. Intracellular $\mathrm{Mg}^{2+}, \mathrm{Ca}^{2+}, \mathrm{Na}^{+}$and $\mathrm{K}^{+}$in platelets and erythrocytes of essential hypertension patients: relation to blood pressure. J. Hypertens., 1992; $14,1189-1209$.

16. R. M. Touyz, F. J. Milne, H. C. Seftel, S. G. Reinach. Magnesium, calcium, sodium and potassium status in normotensive and hypertensive Johannesburg residents. SAMT, 9/1987, vol. 72; 377381.

17. Arvo Haenni, Richard Reneland, Lars Lind and Hans Lithell. Serum aldosterone changes during hyperinsulinemia are correlated to body mass index and insulin sensitivity in patients with essential hypertension. J. Hypertens., 2001; 19, 107-112.

18. Resnick L.M. The effects of sodium and calcium in clinical hypertension: mediating role of Vitamin D metabolism.Adv. Second Messenger Phosphoprotein Res., 1990; 24,535-541.

19. Chlumsky J. Calcium and hypertension. J. Hypertens., 1993; 39, 1181-1184.

20. Yogesh R. Pawade, Suresh S. Ghangale, Indrayani C. Apte, Abhay N. Nagleote, Jayesh P. Warade. Serum calcium: Can it be a diagnostic and prognostic marker in essential hypertension. JCDR, original article/ research, 2011; 5 (1), 58-62. 


\section{ORIGINAL ARTICLE}

\section{AUTHORS:}

1. Arpita B. Patel

2. N. Haridas

3. Hitesh Shah

\section{PARTICULARS OF CONTRIBUTORS:}

1. M.Sc. Student, Department of Biochemistry, Pramukhswami Medical College, Karamsad.

2. Professor and Head, Department of Biochemistry, Pramukhswami Medical College, Karamsad.

3. Professor, Department of Biochemistry, Pramukhswami Medical College, Karamsad.

\section{NAME ADDRESS EMAIL ID OF THE} CORRESPONDING AUTHOR:

Arpita B. Patel, Near Darwaja, Barot Faliya, Lingda, Ta - Umreth Di - Anand,

Gujarat - 388220.

E-mail: arpee_2008p@yahoo.co.in

Date of Submission: 20/04/2013. Date of Peer Review: 22/04/2013.

Date of Acceptance: 07/05/2013.

Date of Publishing: 04/02/2014. 